\title{
Impact of a Surface Sealant Application on the Color Stability of a Nano-hybrid Composite Resin
}

\section{Yüzey Örtücü Uygulamasının Nano-hibrit Kompozit Rezinin Renk Stabilitesi Üzerindeki Etkisi}

(i) Ayça SARIALIOĞLU GÜNGÖR1, id Nazmiye DÖNMEZ1, iD Deniz Selin KAHYA², id Şeyda HERGÜNER SİSO3

${ }^{1}$ Bezmialem Vakıf University Faculty of Dentistry, Department of Restorative Dental Treatment, İstanbul, Turkey

2İstanbul Kent University Faculty of Dentistry, Department of Restorative Dental Treatment, İstanbul, Turkey

3istanbul Aydın University Faculty of Dentistry, Department of Restorative Dental Treatment, İstanbul, Turkey

\begin{abstract}
Objective: Mouthwashes containing chlorhexidine can cause discoloration in restorative materials when used for the long-term. To prevent staining of a restorative material, several protective materials are used. The aim of this in vitro study was to evaluate the impact of a surface sealant on the color stability of a nano-hybrid composite resin material immersed in different mouthwashes.
\end{abstract}

Methods: A total of 42 composite resin discs (10x2 mm) were prepared with a nano-hybrid composite resin (Herculite XRV Ultra) using Teflon moulds. The composite specimens were first divided into two groups (with or without a surface sealant) then into three subgroups $(\mathrm{n}=7)$ according to the mouthwashes (Gengigel, Oderol, and Chlorhex). After SS application to 21 specimens, all the discs were subjected to baseline color measurements using a spectrophotometer according to the Commission Internationale de l'Eclairage $\mathrm{L}^{*} \mathrm{a}^{*} \mathrm{~b}^{*}$ system. The specimens underwent thermal cycling. Following immersion in different mouthwashes for 24 hours, the color measurements were repeated. The $\Delta \mathrm{E}$ data were assessed using Kruskal-Wallis one-way ANOVA. Mann-Whitney U test was performed for different immersion mouthwashes $(\mathrm{p}<0.05)$.

Results: Statistically significant differences $(p<0.05)$ were found between the unsealed composite specimens immersed in Chlorhex and the other mouthwashes in terms of $\Delta \mathrm{E}$ values. The Chlorhex

\section{ÖZ}

Amaç: Klorheksidin içeren ağız gargaraları, uzun süreli kullanıldıklarında restoratif materyallerde renklenmelere neden olabilirler. Restorasyonların renklenmesini önlemek için çeşitli koruyucu materyaller kullanılmaktadır. Bu in vitro çalışmanın amacı, yüzey örtücü bir materyalin farklı ağız gargaralarında bekletilmiş bir nanohibrit kompozit rezinin renk stabilitesi üzerindeki etkisini değerlendirmektir.

Yöntemler: Bir nano hibrit kompozit rezin materyali (Herculite XRV Ultra) kullanılarak 42 adet disk şeklinde kompozit örnekleri (10x2 $\mathrm{mm}$ ) hazırlandı. Örnekler önce iki gruba (yüzey örtücü uygulanan veya uygulanmayan) ardından daldırılan ağız gargaralarına (Gengigel, Oderol ve Chlorhex) göre üç alt gruba (n=7) ayrıldı. Yirmi bir kompozit örneğine yüzey örtücü uygulamasını takiben, tüm disklerin başlangıç renk ölçümleri bir spektrofotometre (Vita Easyshade) kullanılarak Uluslararası Aydınlatma Komisyonu L*a*b* sistemine göre yapıldı. Örneklere termal siklus uygulandı. Yirmi dört saat boyunca farklı ağız gargaralarında bekletilen örneklerin renk ölçümleri tekrarlandı. $\Delta \mathrm{E}$ verileri Kruskal-Wallis tek yönlü one-way ANOVA kullanılarak değerlendirildi. Farklı gargaralar için Mann-Whitney U testi kullanıldı $(\mathrm{p}<0,05)$.

Bulgular: Yüzey örtücü uygulanmamış kompozit örneklerinde, Chlorhex ve diğer gargaralar arasında $\Delta \mathrm{E}$ değerleri bakımından
Address for Correspondence: Ayça SARIALIOČLU GÜNGÖR, Bezmialem Vakıf University Faculty of Dentistry, Department of Restorative Dental Treatment, İstanbul, Turkey

E-mail: aycagungor83@hotmail.com ORCID ID: orcid.org/0000-0002-8779-2949
Received: 01.10.2020

Accepted: 10.01.2021

Cite this article as: Sarıalioğlu Güngör A, Dönmez N, Kahya DS, Hergüner Siso Ş. Impact of a Surface Sealant Application on the Color Stability of a Nano-hybrid Composite Resin.

Bezmialem Science 2022;10(2):219-25 
appeared to be associated with the most severe alteration in color $(5.14 \pm 0.83)$, followed by Gengigel $(2.21 \pm 1.46)$ and Oderol $(1.94 \pm 1.75)$. There were no statistically significant differences ( $p>0.05$ ) between the sealed and unsealed composite specimens in terms of the color changes.

Conclusion: The application of a low viscosity liquid surface sealant material did not show the expected effect on the color stability of a nano-hybrid composite resin in terms of three different mouthwashes.

Keywords: Color change, mouthwash, surface sealant, composite resin, thermal cycling istatistiksel olarak anlamlı farklılıklar $(\mathrm{p}<0,05)$ bulundu. Chlorhex, en şiddetli renk değişikliğine neden olurken $(5,14 \pm 0,83)$, Gengigel $(2,21 \pm 1,46)$ ve Oderol $(1,94 \pm 1,75)$ onu takip etti. Renk değişimleri açısından yüzey örtücü uygulanan ve uygulanmayan örnekler arasında istatistiksel olarak anlamlı bir fark $(p>0,05)$ bulunmadı.

Sonuç: Düşük viskoziteli sıvı bir yüzey örtücü materyalin uygulanması, nano-hibrit bir kompozit rezinin renk stabilitesi üzerinde, üç farklı gargara açısından beklenen etkiyi göstermedi.

Anahtar Sözcükler: Renk değişimi, ağız gargarası, yüzey örtücü, kompozit rezin, termal döngü

\section{Introduction}

A coordinate interaction can occur between the ultimate aesthetic characteristics of dental restoration and the efficacy of the finishing and polishing strategies applied (1). The utilization of solvent polishing liquids with unique systems has been suggested alongside the immediate placement and finishing of resin-based restorative materials. Such an application has been recommended to overcome the various defects feasibly related to the physical characters of the materials as well as the potential faults of the operator (2). The postoperative sealing agents are generally described as rebonding/glazing/liquid-polishing agents or surface sealants (SSs) $(2,3)$. These SSs are placed on the surface of the restoration and the neighbouring tooth structure, thereby boosting the marginal sealing, and also penetrating any surface micro defects and/or gaps formed during the material placement and polymerization $(2,3)$.

The color and surface roughness of the teeth are critical qualities in terms of aesthetics when designing a smile (4). Since the development of composite materials in 1960, attempts have been made to boost the durability of composite restorations. However, as relatively little progress has been made to date, the visual characteristics of these materials still need to be upgraded (5). The color alteration experienced by composites is multifactorial, being related to the intrinsic staining and extrinsic discoloration of the material. The intrinsic factors are related to changes in the chemical balance of the resin matrix and the matrix/particle interface, while the extrinsic factors are associated with the consumption of coloring liquids from exogenous sources related to hygiene, nourishment, and smoking (6).

In recent decades, the number of individuals who use mouthwashes for anti-microbial control has grown, not only due to professional guidance but also due to the capability of such liquids to provide a cooling sensation and to diminish halitosis (7). Mouthwashes have diverse ingredients including alcohol, emulsifiers, organic acids, detergents, and dyes. It should be noted that composite resins exposed to ethanol display decreased microhardness values when compared with non-exposed materials (8). Alcohol appears to act as a plasticizer of the polymeric matrix, thereby making the resin material more ductile (9). Additionally, ethanol can reduce the adhesion between the resin matrix and inorganic fillers, which may increase the softening of the surface and leads to discoloration of the resin material (8).

Endeavors to quantitatively characterize the color alteration experienced by a tooth-colored restoration have been facilitated by the Commission Internationale de l'Eclairage (CIE), which has presented $\mathrm{L}^{*} \mathrm{a}^{*} \mathrm{~b}^{*}$ three-dimensional color estimation system whereby the $\mathrm{L}^{*}$ axis assesses the luminosity or lightness (extending from 0 [black] to 100 [white]), the $\mathrm{a}^{*}$ coordinate assesses the redness $(a>0)$ or greenness $(a<0)$, whereas the $b^{*}$ coordinate assesses the yellowness $(b>0)$ or blueness $(b<0)$ $(10,11)$. The quantitative estimation of the entire alteration in color $(\Delta \mathrm{E})$ hence consolidates a unique equation for a qualitative application relating to both discernment and acceptance limits $(10,11)$.

In dental practice, mouthwashes may need to be used for a long time if the patient is to benefit from both their woundhealing properties and their antibacterial properties. However, chlorhexidine (CHX) can result in a permanent color change following long-term use. Besides, reversible local side effects such as discoloration of teeth, and the tongue, impaired taste sensation (12), increased formation of supragingival calculus and mucous membrane irritation, and desquamation (13) are associated with the use of CHX mouth rinse in long-term use. Oderol mouthwash contains zinc lactate and CHX, although the manufacturer claims that it does not cause discoloration after long-term use. Gengigel, which is a hyaluronic acid mouthwash, is marketed offering a wound-healing potential. To the best of our knowledge, no studies have yet examined the discoloration associated with both Oderol and Gengigel in composite restorations following long-term use.

The first aim of this study was to evaluate the long-term use of three different types of mouthwash on the color stability of composite restorations. The second aim of this study was to assess the effect of SS application on the coloration resistance of a nanohybrid resin composite soaked in different types of mouthwash. The null hypothesis was that the application of a SS would not be able to protect the color stability of a nano-hybrid composite restoration after using different mouthwashes in the long-term. 


\section{Method}

\section{Sample Preparation}

Forty-two disc-shaped specimens $(10.0 \mathrm{~mm}$ inner diameter $\mathrm{x} 2.0$ $\mathrm{mm}$ thickness) were prepared in Teflon moulds utilizing the Herculite XRV Ultra (Kerr Corporation, Orange, CA, USA) shade A2 nanohybrid composite material. Each material was covered with transparent polyethylene matrix strips (Kerr Hawe Striproll, Kerr Corporation, Orange, CA, USA) on each side to ensure a uniform finish. The composite resins were compressed between two microscopic glass slides to expel any excess material. Photopolymerization was performed for 20 seconds using a VALO Cordless (Ultradent Products Inc., South Jordan, USA) light-emitting diode (LED) device with an irradiance of 1,800 $\mathrm{mW} / \mathrm{cm}^{2}$. The directly lighted surfaces were progressively polished using aluminium oxide polishing discs (Sof-Lex, 3M ESPE, St Paul, MN, USA). A single operator performed the polishing process with a low-speed handpiece at around 4,000$5,000 \mathrm{rpm}$. Each disc was used on a surface for $15 \mathrm{~s}$. Then, the polished surfaces were water-rinsed for $60 \mathrm{~s}$ to expel any surface debris. Afterward, they were air-dried for $30 \mathrm{~s}$. The thickness of each sample was checked using a digital calliper (Yamer, İzmir, Turkey). To guarantee the absence of any deformities, the surfaces were inspected under a metallographic microscope (ME 600 Eclipse, Nikon-Kogaku, Tokyo, Japan). Then, the specimens were submerged in artificial saliva (14) (1 $\mathrm{L}$ aqua, $0.1 \mathrm{~g} \mathrm{H}_{3} \mathrm{BO}_{3}$, $2.4 \mathrm{~g} \mathrm{KCl}, 1.7 \mathrm{~g} \mathrm{NaCl}, 0.1 \mathrm{~g} \mathrm{MgCl}_{2} \cdot 6 \mathrm{H}_{2} \mathrm{O}, 0.2 \mathrm{~g} \mathrm{CaCl}_{2} \cdot 2 \mathrm{H}_{2} \mathrm{O}$, $\left.0.2 \mathrm{~g} \mathrm{KSCN}, 0.7 \mathrm{~g} \mathrm{KH}_{2} \mathrm{PO} 4\right)$ and stored in an incubator (Memmert GmbH, Schwabach, Germany) at a temperature of $37 \pm 1{ }^{\circ} \mathrm{C}$ for $24 \mathrm{~h}$ to provide complete polymerization.

Twenty-one of the specimens were etched with 37\% phosphoric acid (Etchant Gel; Prime Dent, Chicago, IL, USA) for 15 s, then washed with distilled water and air-dried. Later, the BisCover LV SS was applied directly using a micro brush for $15 \mathrm{~s}$. The top surfaces of the specimens were tenderly air-thinned for $3 \mathrm{~s}$ and then lightcured for $30 \mathrm{~s}$, as recommended in the manufacturer's instructions, using a LED light unit. The other twenty-one specimens remained unsealed. The compositions of all the materials used in this study were detailed in Table 1 . The specimens were stored in artificial saliva at $37 \pm 1^{\circ} \mathrm{C}$ for $24 \mathrm{~h}$ to provide complete polymerization of the SS. At that point, all the specimens were subjected to ageing through 1,500 thermal cycles (SD Mechatronik GmbH, FeldkirchenWesterham, Germany) at temperatures rotating between $5{ }^{\circ} \mathrm{C}$ and $55^{\circ} \mathrm{C}$ with a stay time of $30 \mathrm{~s}$ in each water bath (15).

After the thermocycling, the specimens were divided into three groups $(\mathrm{n}=14)$ based on the mouthwash in which they would be immersed (Table 1): Group 1 - Gengigel, Group 2 - Oderol, and Group 3 Chlorhex. The specimens were stored in $20 \mathrm{~mL}$ of each mouthwash for $24 \mathrm{~h}$, which was equivalent to $2 \mathrm{~min} /$ day of mouthwash use for two years (16). The specimens within the mouthwashes were kept at $37^{\circ} \mathrm{C}$ throughout the experiment, and they were shaken every $3 \mathrm{~h}$ to ensure their homogeneity (17). At the end of the experiment, the specimens were evacuated and then submerged in distilled water.

\section{Color Measurements}

Following the application of the surface sealant to 21 composite specimens, the baseline color measurement of all the specimens was performed under a white background (Gardner Laboratory Inc., Bethesda, MD, USA) using a spectrophotometer (Vita Easyshade, Vita Zahnfabrik, Bad Säckingen, Germany). This device is specifically designed for colour measurement. Before the measurement, the top surface of each sample was dried using tissue paper and the contact guide of the spectrophotometer was situated at the center of the sample's surface. Three successive readings were taken for each sample and then averaged.

After thermal cycling and immersion of all 42 composite specimens in the mouthwashes for $24 \mathrm{~h}$, the color measurements were repeated as detailed above. Based on the $L^{*}, a^{*}$, and $b^{*}$ values, the overall color change $(\Delta \mathrm{E})$ was calculated using the following equation:

$\Delta \mathrm{E}=\left[\left(\Delta \mathrm{L}^{*}\right)^{2}+\left(\Delta \mathrm{a}^{*}\right)^{2}+\left(\Delta \mathrm{b}^{*}\right)^{2}\right]^{1 / 2}(18)$.

$\Delta \mathrm{E}$ values $\geq 3.3$ were considered to be clinically improper (19).

\section{Statistical Analysis}

The distribution of the data was determined using the ShapiroWilk test.

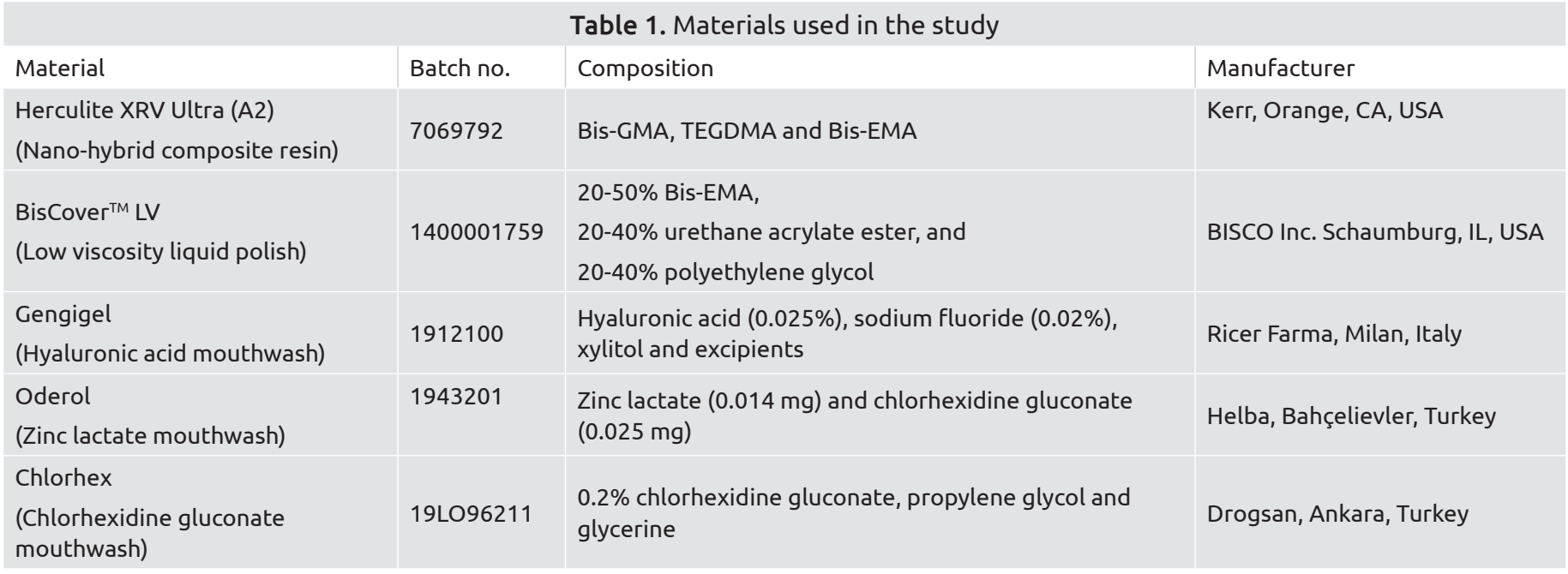


Due to the non-normal distribution of the data, the differences in the color changes $\left(\Delta \mathrm{L}^{*}, \Delta \mathrm{a}^{*}, \Delta \mathrm{b}^{*}\right.$ and $\left.\Delta \mathrm{E}\right)$ between the different mouthwash groups were analyzed using a Kruskal-Wallis oneway ANOVA. To assess the differences between the sealed and unsealed groups, a Mann-Whitney U test was performed. Data were submitted for statistical analysis at the $\mathrm{p}=0.05$ level of significance. The statistical calculations were performed using SPSS for Windows 24.0 (SPSS Inc., Chicago, IL, USA).

\section{Results}

The mean, standard deviation, and median (minimummaximum) of the $\Delta \mathrm{E}$, as well as of the $\Delta \mathrm{L}, \Delta \mathrm{a}$, and $\Delta \mathrm{b}$ values, for the sealed and unsealed groups following immersion in different mouthwashes, are presented in Tables 2 and 3.

Statistically significant differences were found between $\Delta \mathrm{E}$ values of the specimens without surface sealant but immersed in Chlorhex and the other mouthwashes tested. Chlorhex showed a greater degree of color alteration ( $\mathrm{p}<0.05$ ), followed by Gengigel and Oderol (Table 2).

Regarding the SS, statistically significant differences $(\mathrm{p}<0.05)$ were found between the groups in relation to the $\Delta \mathrm{a}$ values (sealed and unsealed), except for Oderol and Chlorhex groups (Table 3).
Concerning the tested mouthwash solutions, no statistically significant differences were found between the groups ( $p>0.05$ ) (in relation to the $\Delta \mathrm{L}, \Delta \mathrm{a}$, and $\Delta \mathrm{b}$ values), except for the $\Delta \mathrm{L}$ values in the Chlorhex group $(\mathrm{p}<0.05)$ (Table 3$)$.

\section{Discussion}

The null hypothesis was partially accepted in this study. Although there was a considerable increase in $\Delta \mathrm{E}$ values after the SS application (except for Chlorhex group), no statistically significant difference in color was observed between the sealed and unsealed composite specimens ( $p>0.05$ ). The preservation of the color throughout the functional period of dental restorations is one of the foremost aesthetic characteristic considerations concerning composite materials. However, this characteristic is not consistent among the different available restorative materials. In our study, we used a nano-hybrid composite material that could be used both in the anterior and posterior restorations, due to the superior polishability, better optical and aesthetic properties, and less polymerization shrinkage (20). Chairside polishing of composite resins with sealant agents should provide improved stain resistance. However, the success and longevity of these sealant agents on composite resin restorations are still unknown. Since one of our purposes in the study was to evaluate the effect of a surface sealant on the color stability, we preferred to choose only one resin composite material.

Table 2. $\Delta \mathrm{E}$ median (min-max) and mean \pm standard deviation of the experimental groups

\begin{tabular}{|c|c|c|c|c|c|}
\hline & \multicolumn{2}{|c|}{ Without sealant } & \multicolumn{2}{|l|}{ With sealant } & \multirow[t]{2}{*}{$\mathrm{p}$} \\
\hline & Mean \pm SD & Median (min/max) & Mean \pm SD & Median (min/max) & \\
\hline Gengigel & $2.21 \pm 1.46^{\mathrm{aA}}$ & $2.03(0.7 / 4.5)$ & $3.09 \pm 0.65^{\mathrm{aA}}$ & $2.9(2.3 / 4.42)$ & 0.445 \\
\hline Chlorhex & $5.14 \pm 0.83^{\mathrm{bA}}$ & $5.22(4.27 / 6.73)$ & $4.02 \pm 1.71^{\mathrm{aA}}$ & $3.6(0.7 / 6.72)$ & 0.234 \\
\hline$p$ & \multicolumn{2}{|l|}{0.005} & \multicolumn{2}{|l|}{0.815} & \\
\hline
\end{tabular}

Table 3. $\Delta \mathrm{L}, \Delta \mathrm{a}, \Delta \mathrm{b}$ median (min-max) and mean \pm standard deviation of the experimental groups

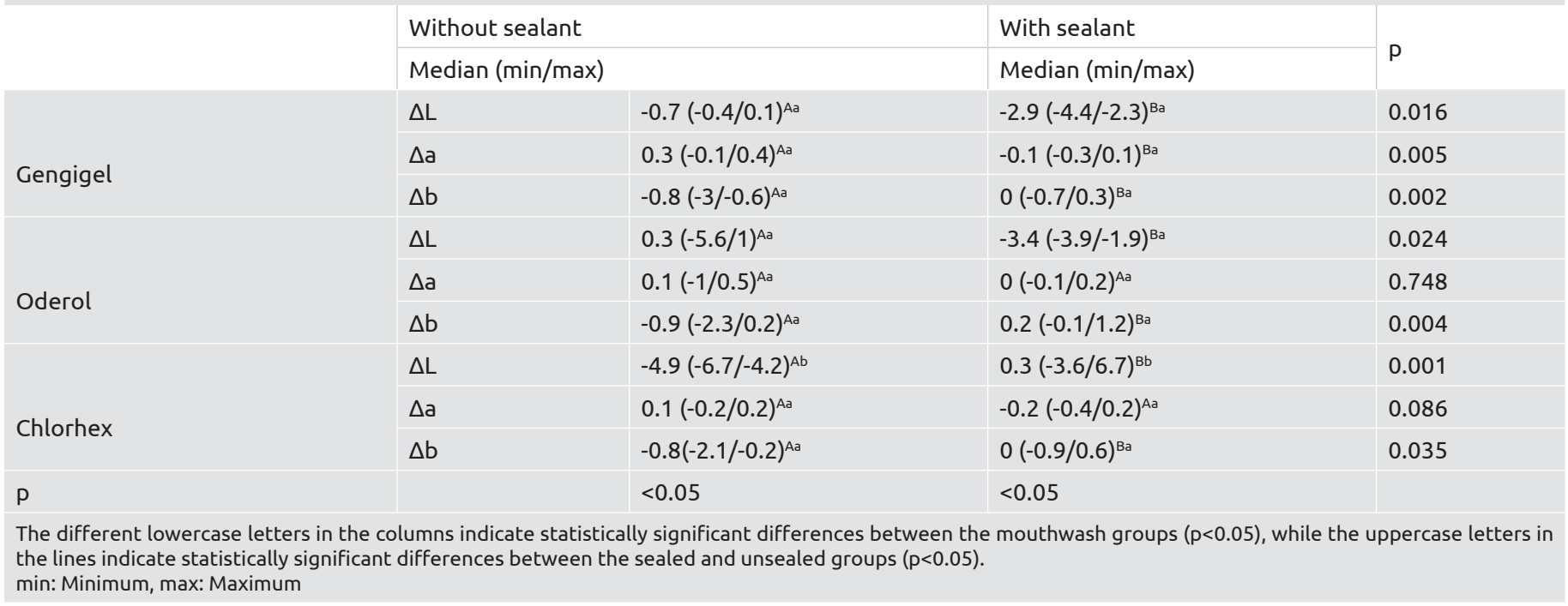


In most prior studies, a spectrophotometer was used in accordance with the CIE's $\mathrm{L}^{*} \mathrm{a}^{*} \mathrm{~b}^{*}$ framework to measure the $\Delta \mathrm{E}$ values $(21,22)$. This electronic device uses a normal light in a dark component, separated from the surrounding light, to measure the color and, thus, the results are convincing, definitive, and quotable. The $\Delta \mathrm{E}$ value of composite resins that is greater than 3.3 indicates a clinically critical and unacceptable color change (18).

The color stability of aesthetic composite restorations is influenced by several extrinsic and intrinsic variables. Extrinsic discoloration results from factors such as poor oral hygiene, dietary, and smoking patterns. The use of mouthwash is another extrinsic variable that influences the color stability of aesthetic composite restorations. Yet, the use of mouthwash is also known to help control caries and periodontal illnesses $(23,24)$. Therefore, in our study, we evaluated the staining effect of two different mouthwashes with very high periodontal effectiveness, containing different concentrations of CHX gluconate as well as a mouthwash containing hyaluronic acid.

In the present study, all mouthwashes caused a color alteration on the composite resins. The Chlorhex with a $\Delta \mathrm{E}$ value of 5.22 was found as the mouthwash that caused the greatest degree of color alteration among all the tested mouthwashes (Table 2). This high value has been characterized as unacceptable for in vitro conditions (25). The absorption of the alcohol particles contained in mouthwashes into the resin matrix may result in the softening of the composite resin's surface and so contribute to its discoloration, which may explain the outcomes observed for Chlorhex (26). One of the mouthwashes tested in this study was Oderol. It incorporates zinc, which is an essential element in plaque, saliva, and enamel. Zinc is added to oral healthcare products to control plaque and to prevent calculus formation. In the presence of plaque and saliva, its permanence may persist for hours in the oral environment (27). According to our findings, the specimens immersed in Oderol, which contained a lower amount of CHX gluconate $(0.025 \mathrm{mg})$ than Chlorhex, did not show unacceptable levels of color change. This acceptable color change may be due to the concentration of CHX gluconate mouthwash ranging from $0.2 \%$ to $0.12 \%(28)$.

The mechanism of staining by CHX gluconate is not known exactly. In the literature, three possible mechanisms were reported (29). 1) CHX may increase the non-enzymatic browning reaction of protein and carbohydrate in the acquired pellicle; 2) CHX denatures components within the dental pellicle, accelerate the formation of pigmented sulfides of iron; 3) CHX precipitates dietary chromagens. According to our results, Chlorhex with a higher concentration of CHX gluconate caused the most severe color alteration of all mouthwashes. The use of CHX gluconate mouthrinse has been reported to cause staining in earlier studies $(28,30,31)$. From this perspective, this study carries confirmatory value.

The use of an SS, which comprises BIS-GMA, UDMA, and TEG-DMA without filler particles, may assist with removing or minimizing the color variations seen in relation to composite resins. Such materials are characterized by low thickness and high usefulness (32). The use of a SS serves to fill any microstructural defects of the surface and so decreases the surface roughness and the presence of bubbles. Different opinions exist as to the SS, which can alter the surface properties, color stability, marginal microleakage, and optical properties of composite resins $(33,34)$.

There are contradictions among the results of previous studies in this area $(24,33,35)$. According to Doray et al. (33), SS can promote the resistance of temporary composite resin immersed in red wine, coffee, and cranberry juice to staining. However, Soares et al. (35) applied a reflectance analysis and showed that the coffee-related surface coloring was higher in the groups that applied SS. Similar to the results of the present study, Lee and Powers (24) stated that the color alterations seen in the sealed group subjected to staining by CHX, tea, and mucin were not notably different when compared to those seen in the unsealed group. Differences in the chemistry, polymerization approaches, and thicknesses of the sealants may impact their sensitivities to coloring. Regarding the current study, an unexpected phenomenon occurred after the polymerization of SSs on the surfaces of the composite samples. Although the initial appearance was a glossy surface, air bubbles formed in the sealant material during the application with a brush, might provide a suitable environment for the discoloration of the material, as they created irregular areas on the restoration surface after polymerization. The variations between the $\Delta \mathrm{E}$ values of the tested specimens in the present study may also be attributed to the long-term immersion in the mouthwashes, which destroys the integrity of the SS layer. This destroying could lead to microcrack formations and the removal of nonadherent surface particles. The increased thickness of the sealant agent may be responsible for the various degrees of discoloration and deterioration of the surface sealant (24). Based on these, it can be said that the SS application may have no positive effect (33).

The discoloration of composite resins can be considered in relation to their degree of water absorption and the hydrophilicity of the resin matrix (36). If the resin matrix can retain water, it is also able to retain any other liquid, which eventually leads to discoloration. Extraordinary water absorption induces the extension and plasticization of the composite, as well as the hydrolysis of the silane, which in turn forms microcracks and so leads to the decreased durability of the composite restoration (37). Indeed, microcracks or interfacial gaps at the intersection between the filler and the matrix permit stain infiltration and so facilitate discoloration $(23,37)$.

In the formulation of Herculite XRV Ultra, TEGDMA was included to decrease the viscosity of the Bis-GMA resin. While the TEGDMA was included to enhance the handling features, it also resulted in water sorption ability (37). In fact, the hydrophilic characteristics of the TEGDMA lead to extraordinary water sorption, which prompts the extension and plasticizing of the Bis-GMA resin, and causes a reduction in the longevity of the composite resin. It has been reported that hydrophilic materials show a high degree of water absorption and, they become more colored with staining agents than hydrophobic materials (38). 
Although Herculite XRV Ultra, a nano-hybrid composite resin, was expected to show less discoloration due to its small particle size, it showed a high degree of discoloration when immersed in mouthwashes. This can be attributed to the structure of the resin matrix (UDMA, TEGDMA, Bis-EMA) and the different sizes of the filler particles.

The results of this study showed that the color changes on composite specimens exposed to different types of mouthwash for 24 hours were not clinically acceptable $(\Delta \mathrm{E}>3.3)$. Regarding the color parameters $\left(\mathrm{L}^{*} \mathrm{a}^{*} \mathrm{~b}^{*}\right)$, the results indicated that the $\Delta \mathrm{L}$ values were negative, which showed that the composite samples became darker in all groups (except for the Chlorhex group). It was reported that color change for dimethacrylate based composites was mostly caused by $\Delta \mathrm{L}^{*}$ and $\Delta \mathrm{b}^{*}$ (39). In terms of $\mathrm{a}^{*}$ axis, the colors of the composite samples immersed in mouthwashes shifted from red towards green after SS application. In relation to the $\mathrm{b}^{*}$ axis, the colors of the nanohybrid composite samples shifted from blue towards yellow after SS application (Table 3). Yellowing was most likely due to a reaction involving the many unreacted methacrylate groups (approximately 40\%) present within the composite resin. The visual yellowing of BIS-GMA itself during UV illumination in the presence of oxygen implies that some chemical alteration of the resin itself may be one of the principal causes of the yellowing in dental composites (40).

\section{Study Limitations}

It is important to recognize the methodological limitations of in vitro studies designed to determine color stability. To accelerate the ageing progress, in vitro studies aim to simulate the impacts of long-term exposure in an oral environmental. Within the oral environment, the saliva and other liquids may dilute the stains. The first limitation of this study was not keeping the samples in artificial saliva as in the oral environment and not immersing them for a long time. Already, exposure of dental structures and restorative materials to the coloring agents in the oral environment is not continuous and the discoloration can be accelerated by mechanical wear. The second limitation of this study was that mechanical wear was not imitated. Besides, choosing only one composite resin and one surface sealant, and the lack of brushing effect with or without a toothpaste were the other limitations of the study.

\section{Conclusion}

Within the limitations of this study, it could be concluded that long-term use of mouthwash causes discoloration on a composite resin restoration. Besides, the application of a low viscosity liquid surface sealant material did not show the excepted effect on the color stability of a nano-hybrid composite resin in terms of three different mouthwashes.

\section{Ethics}

Ethics Committee Approval: Ethics committee approval is not required since our study was conducted with composite resin samples and no patient or dental samples were used.
Peer-review: Externally peer reviewed.

\section{Authorship Contributions}

Concept: A.S.G., N.D., Ş.H.S., Design: A.S.G., N.D., Data Collection or Processing: A.S.G., D.S.K., Analysis or Interpretation: A.S.G., N.D., Literature Search: A.S.G., N.D., D.S.K., Ş.H.S., Writing: A.S.G.

Conflict of Interest: No conflict of interest was declared by the authors.

Financial Disclosure: The authors declared that this study received no financial support.

\section{References}

1. Güler AU, Güler E, Yücel AC, Ertaş E. Effects of polishing procedures on color stability of composite resins. J Appl Oral Sci. 2009; 17:108-12.

2. Itoh K, Iwaku M, Fusayama T. Effectiveness of glazing composite resin restorations. J Prosthet Dent 1981;45:606-13.

3. Trushkowsky RD. Attributes of a surface-penetrating sealant. Contemporary Esthetics and Restorative Practice 2004(June):52-54.

4. Samra AP, Pereira SK, Delgado LC, Borges CP. Color stability evaluation of aesthetic restorative materials. Braz Oral Res 2008;22:205-10.

5. Cruvinel DR, Garcia Lda F, Consani S, de Carvalho Panzeri Piresde-Souza F. Composites associated with pulp-protection material: color-stability analysis after accelerated artificial aging. Eur J Dent 2010;4:6-11.

6. Dietschi D, Campanile G, Holz J, Meyer JM. Comparison of the color stability of ten new-generation composites: an in vitro study. Dent Mater 1994;10:353-62.

7. DeVore LR. Antimicrobial mouthrinses: impact on dental hygiene. J Am Dent Assoc 1994;125(Suppl 2):23S-28S.

8. Schneider LF, Moraes RR, Cavalcante LM, Sinhoreti MA, CorrerSobrinho L, Consani S. Cross-link density evaluation through softening tests: effect of ethanol concentration. Dent Mater 2008;24:199-203.

9. Sarrett DC, Coletti DP, Peluso AR. The effects of alcoholic beverages on composite wear. Dent Mater 2000;16:62-7.

10. Gomez-Polo C, Portillo Munoz M, Lorenzo Luengo MC, Vicente P, Galindo P, Martin Casado AM. Comparison of the CIELab and CIEDE2000 color difference formulas. J Prosthet Dent 2016;115:65-70.

11. Paravina RD. Critical appraisal. Color in dentistry: match me, match me not. J Esthet Restor Dent 2009;21:133-9.

12. Pader M. Oral Hygiene Products and Practice. 1st ed. New York: Dekker Inc. 1988.

13. Mandel ID. Chemotherapeutic agents for controlling plaque and gingivitis. J Clin Periodontol 1988;15:488-98.

14. Schmidlin P, Zobrist K, Attin T, Wegehaupt F. In vitro re-hardening of artificial enamel caries lesions using enamel matrix proteins or selfassembling peptides. J Appl Oral Sci 2016;24:31-6. 
15. Poggio C, Dagna A, Chiesa M, Colombo M, Scribante A. Surface roughness of flowable resin composites eroded by acidic and alcoholic drinks. J Conserv Dent 2012;15:137-40.

16. el-Badrawy WA, McComb D, Wood RE. Effect of home-use fluoride gels on glass ionomer and composite restorations. Dent Mater 1993;9:63-7.

17. Gürdal P, Akdeniz BG, Hakan Sen B. The effects of mouthrinses on microhardness and colour stability of aesthetic restorative materials. J Oral Rehabil 2002;29:895-901.

18. Aguilar FG, Roberti Garcia Lda F, Cruvinel DR, Sousa AB, de Carvalho Panzeri Pires-de-Souza F. Color and opacity of composites protected with surface sealants and submitted to artificial accelerated aging. Eur J Dent 2012;6:24-33.

19. Ruyter IE, Nilner K, Moller B. Color stability of dental composite resin materials for crown and bridge veneers. Dent Mater 1987;3:246-51.

20. Mitra SB, Wu D, Holmes BN. An application of nanotechnology in advanced dental materials. J Am Dent Assoc 2003;134:1382-90.

21. Archegas LR, Freire A, Vieira S, Caldas DB, Souza EM. Colour stability and opacity of resin cements and flowable composites for ceramic veneer luting after accelerated ageing. J Dent 2011;39:804-10.

22. Lepri CP, Palma-Dibb RG. Influence of surface sealant on the colorstability of a composite resin immersed in different beverages. Oral Health Dent Manag 2014;13:600-4.

23. Bagheri R, Burrow MF, Tyas M. Influence of food-simulating solutions and surface finish on susceptibility to staining of aesthetic restorative materials. J Dent 2005;33:389-98.

24. Lee YK, Powers JM. Combined effects of staining substances on resin composites before and after surface sealant application. J Mater Sci Mater Med 2007;18:685-91.

25. Khashayar G, Bain PA, Salari S, Dozic A, Kleverlaan CJ, Feilzer AJ. Perceptibility and acceptability thresholds for colour differences in dentistry. J Dent 2014;42:637-44.

26. Villalta P, Lu H, Okte Z, Garcia-Godoy F, Powers JM. Effects of staining and bleaching on color change of dental composite resins. J Prosthet Dent 2006;95:137-42.

27. Lynch RJ. Zinc in the mouth, its interactions with dental enamel and possible effects on caries; a review of the literature. Int Dent J 2011;61(Suppl 3):46-54.

28. Bagis B, Baltacioglu E, Özcan M, Ustaomer S. Evaluation of chlorhexidine gluconate mouthrinse-induced staining using a digital colorimeter: an in vivo study. Quintessence Int 2011;42:213-23.
29. Watts A, Addy M. Tooth discolouration and staining: a review of the literature. Br Dent J 2001;190:309-16.

30. Ellingsen JE, Rolla G, Eriksen HM. Extrinsic dental stain caused by chlorhexidine and other denaturing agents. J Clin Periodontol 1982;9:317-22.

31. Carpenter GH, Pramanik R, Proctor GB. An in vitro model of chlorhexidine-induced tooth staining. J Periodontal Res 2005;40:225-30.

32. Garcia PPNS, Neto ER, Santos PAD, Campos JADB, Dibb RGP. Influence of Surface Sealant on the Translucency of Composite Resin: Effect of Immersion Time and Immersion Media. Materials Research 2008;11:193-7.

33. Doray PG, Eldiwany MS, Powers JM. Effect of resin surface sealers on improvement of stain resistance for a composite provisional material. J Esthet Restor Dent 2003;15:244-9.

34. Kazak M, Yurdan R, Donmez N, Koymen SS. Marginal Microleakage of Composite Resin Materials Comprising Different Photo Initiators with Surface Sealants and Bonding Agent Application after Thermomechanical Aging. Journal of Research in Medical and Dental Science 2020;8:16-25.

35. Soares LE, Cesar IC, Santos CG, De Cardoso AL, Liporoni PC, Munin E, et al. Influence of coffee on reflectance and chemistry of resin composite protected by surface sealant. Am J Dent 2007;20:299-304.

36. Chandrasekhar V, Reddy LP, Prakash TJ, Rao GA, Pradeep M. Spectrophotometric and colorimetric evaluation of staining of the light cured composite after exposure with different intensities of light curing units. J Conserv Dent 2011;14:391-4.

37. Ferracane JL. Hygroscopic and hydrolytic effects in dental polymer networks. Dent Mater 2006;22:211-22.

38. Reis AF, Giannini M, Lovadino JR, Ambrosano GM. Effects of various finishing systems on the surface roughness and staining susceptibility of packable composite resins. Dent Mater 2003;19:12-8.

39. Perez MM, Ghinea R, Ugarte-Alvan LI, Pulgar R, Paravina RD. Color and translucency in silorane-based resin composite compared to universal and nanofilled composites. J Dent 2010;38(Suppl 2):110-6.

40. Ferracane JL, Moser JB, Greener EH. Ultraviolet light-induced yellowing of dental restorative resins. J Prosthet Dent 1985;54:483-7. 